\title{
Introduction to "This Is Not Normal"
}

\author{
David Arditi, Timothy W. Luke
}

As we prepared this issue of Fast Capitalism for publication, we could not foresee how incredibly "not normal" almost all public affairs in the United State things would become. After the murders of George Floyd and Breonna Taylor, the outrage about state-tolerated police violence against Black people turned to rage. Protests exploded with uncontained fury in scores of cities across the United States. When governors and mayors imposed curfews, many police officers took this as a signal to release their own rage on peaceful protestors, African Americans, and journalists. The palpable fear and anger among protestors only accentuated the extraordinary levels of this state executed violence. Protests against police brutality suddenly shifted on live television broadcasts into more police violence by more threatening tactical law enforcement personnel. Following three years of President Donald Trump stating that the news media are "enemy number one," it is not a big leap for the police to target journalists reporting on democratic protests with pepper spray, rubber bullets, tear gas, and flash bang grenades.

Indeed...this is not normal.

In recent decades, Americans presidents have called for calm in the face of such egregious acts. Often these empty platitudes were enough deescalate the confrontations and relieve steam from the pressure cooker of partisan division. These rhetorical platitudes can be heard in messages from former presidents Barrack Obama and George $W$. Bush during the first weeks of June. The brutal murder of George Floyd in broad daylight on a Minneapolis street under the knee of a Minnesota policemen while three fellow officers stood by seemingly indifferent to Floyd's slow strangulation should have prompted an Oval Office address calling for a careful criminal inquest into such an injustice. Such empathy, integrity or respect, however, is not Trump's governing style. Instead, the President went golfing and tweeting. His tweets blamed "thugs" for the street violence and he alluded to for shooting protesters using a famous quote from racist Miami police Chief Walter Headley in 1967 and 1968 about his riot control philosophy: "when the looters start, the shooting starts."

This is not normal.

On a phone call with all 50 US governors, Trump called the governors "weak" and advocated that they use force against protesters (Costa, Seung Min Kim, and Josh Dawsey n.d.). In his tirade, which people on the call described as "unhinged," he claimed he would take military action by putting the joint chiefs of staff and the secretary of defense in charge. "You have to dominate. If you don't dominate, you're wasting your time. They're going to run over you. You're going to look like a bunch of jerks. You have to dominate," Trump decried (Burns 2020). His goal was to move beyond the slow militarization of urban police forces since the 1960s to the milita-

rized occupation of American cities in 2020.

This is not normal. 
U.S. Customs and Border Patrol personnel were redeployed to Washington, DC to get in on this action along with National Guard forces from ten states and various other federal police agencies. Some elements of these hastily mobilized new security forces invaded Washington, DC without any insignia of service or unit identification in violation of military codes of conduct or even regular badges showing what police force they represent (both requirements under DC law). These street-fighting storm trooper tactics are emblematic of brutal actions taken by authoritarian regimes across the world. For President Trump, domineering swagger is mandatory for showing "who's boss," but showing force against largely peaceful demonstrators exercising their rights of assembly and free speech reveals the twisted soul of an elected leader unworthy of having such authority in a democracy.

This is not normal.

Trump then took an unprecedented action for a photo-op to broadcast to his political base. At his direction, Attorney-General William Barr ordered federal security contingents to clear Lafayette Park in front of the White House. A mixed contingent of federal police and military forces attacked peaceful demonstrators before curfew after issuing perfunctory directives for them to disperse. They hit peaceful lawfully present protestors with tear gas and rubber bullet, forcing them back from the park with shields and horses. After the park. was clear, Trump calmly walked across the street to St. John's Episcopal church to make a live broadcast holding a copy of the Bible to declare himself the agent of "Law and Order" and decry the protestor ultimately as terrorists. His aim was to cast himself in a moment of historic resolve against malign forces in a script that likened him to Winston Churchill in 1940 defying the blitz, or George W Bush at the smoldering World Trade Center ruins after 9/11/2001. Instead, these strong-arm antics resembled a tin-horn demagogue bellbent on putting the unruly masses in their proper place of debumanized domination.

This is not normal.

Ironically, in the weeks before Floyd's murder, Trump supporters protested "stay at home" orders to control the COV ID-19 pandemic, committed violence against people wearing sterile masks for everyone's personal safety, and armed self-proclaimed militia groups stormed the Michigan State Capitol "to liberate" the people from the allegedly misguided leadership of the state's female Democratic governor. Trump's reaction to these putatively patriotic right-wing action groups protesting shelter-in-place orders was positive. Indeed, he too called for the end of shelter-in-place and face masks orders during a pandemic as mindless policies that were killing hundreds of thousands of American jobs and ruining his heroic recovery of jobs for the nation. Trump saw restrictions of movement for public health as unconstitutional, but he regarded protests against police violence as disorderly, illegal, and un-American.

This is not normal.

In a move reminiscent of the Nazi Party's irregular paramilitary "Brownshirts," the Trump-Pence campaign began selling camo "Keep America Great" (KAG) hats on their website. Trump wants to recast his followers as volunteers to serve as a "Trump Army." Such an invitation is exciting for many of his followers, since they already show up to many protests openly carrying firearms and wearing tactical field gear. His campaign states to the "Trump Army" that "YOU are the President's first line of defense when it comes to fighting off the Liberal $M O B$ " (See Figure 1). Since his new federal police forces are often unmarked, there would be nothing to stop the "Trump Army" from showing up to assault protestors, because there would be no way to identify who might bave "legitimate" authority. Of course, in Trump's own advertising of the camo KAG bats, Trump brazenly pretends to give his personal authority to these new partisans for "keeping America great." Such unlanful presumptions by the Trump/Pence Re-Election Campaign can be cynically dismissed as a wry amusing effort to market "bis message" to his embattled political base. Yet, these values, practices, and ideas have contorted the Re- 
publican Party in many states into dreadful caricatures that bears no resemblance to their once more progressive, egalitarian, and unifying visions of America's popular government. These paternalistic acts of ultranationalist oligarchy instead appear to be unconstitutional steps down a road that could lead the United States toward more openly authoritarian, if not fascist, modes of rule.

This is not normal...

David Arditi and Timothy Luke

6.6.2020

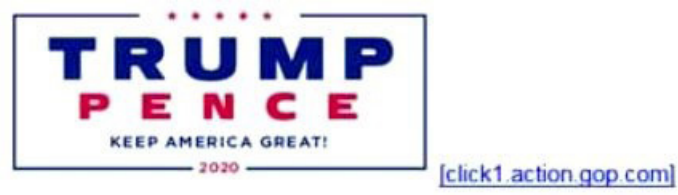

Friend,

This email is FOR PATRIOTS ONLY.

You've been identified as one of President Trump's fiercest and most loyal defenders, and according to your donor file, you'd make an excellent addition to the Trump Army.

When you become a member of the Trump Army today, we'll give you access to get our neverbefore-seen, Limited Edition Camo Keep America Great Hat.

The President wants YOU and every other member of our exclusive Trump Army to have something to identify yourselves with, and to let everyone know that YOU are the President's first line of defense when it comes to fighting off the Liberal MOB.

These limited-edition. American-made hats are for Trump Army members ONLY, so do not pass this information on to anyone.

Please contribute $\$ 35$ or more RIGHT NOW to join the Trump Army and we'll send you your very own Camo Keep America Great Hat. > [click1.action.gop.com]

Official KEEP AMERICA GREAT HAT

Figure 1. Email from Trump-Pence Campaign.

In writing the introduction to this special issue of Fast Capitalism, I am following Tarrant County, Texas' "Shelter-at-Home" order due to the COVID-19 Pandemic. When our call for a special issue entitled "This Is Not Normal" about the Trump era went out last year, we could never have predicted how extraordinarily abnormal our everyday life soon would become in 2020. However, the more fundamental changes in everyday life after the pandemic are not at issue here. Rather, President Donald J. Trump's handling of the pandemic's health crisis and its 
ensuing economic crisis crisply highlights many of the common failures of his "not normal" style of governance. For months, President Trump decried the coronavirus as nothing but the Democratic party's new "hoax," most publicly at a February $28^{\text {th }}$ rally at a time when more than a dozen Americans had already been diagnosed with the disease (Obeidallah 2020). To add insult to injury, he continued to oscillate between casting COVID-19 as a legitimate national threat and depicting it as something the Democrats and "the media" (minus Fox News, of course) had overblown. Even as Trump tried to shift to a more serious approach to coronavirus, he appointed Kayleigh McEnany, a known coronavirus-denier, as the new White House Press Secretary (Blake 2020). While our nearly nation-wide lockdown constitutes a moment of extreme abnormality, the Trump Administration's response to the current epidemic and economic crisis exemplifies the many ways in which the Trump presidency is not normal.

When we first made the call for this special issue, we saw the impeachment of Trump on the horizon, but we did not know that it would have much to do with Ukraine. At the time, America was entering full swing into a wild presidential election with considerable focus paid to the Mueller Report on Russia's interference in the 2016 election. I thought the clear evidence, and the attempted cover-up of the report by Attorney General William Barr was enough to impeach Trump. But times are not normal. Apparently, Special Counsel Robert Mueller did not generate gripping enough television to impeach the president, so Congress packed up for its August recess with little planning to convene the impeachment process. President Trump's use of spectacle (Kellner 2019) has altered most of the scripts for mass media democracy as a political game to reinvent as a $24 \times 7$ Twitter and television multi-media circus. No matter how damning and compelling any public information proves to be, if it does not provide good television, then it is rapidly rendered irrelevant.

Our initial call for contributions to this volume stated the following:

A popular refrain heard from citizens, journalists, and politicians in the news media describes Donald Trump's actions as "not normal." At the same time, there has been a consistent effort to normalize his actions in the Republican Party, the White House, and some media outlets as well as many social media streams. By July 2019, public discourse has reached the point that the President's tweets that four liberal, non-white congresswomen should "go back" to their own countries seems to many like ordinary common sense on another Sunday, and such comments do little to nothing to weaken his support among his Republican base. In turn, this "not normal" loss of basic civility between the White House, the Democratic majority in the House, and many ordinary citizens begins to look far more like an acceptable new normality as too many others in public life emulate him.

As 2020 approaches, Trump's new national order of "not normal" pushes further and further towards demagoguery, authoritarianism, and illegality. From his interview in which he said he "would like to hear" information from a foreign government to get dirt on political opponents to hinting that a win in 2020 could enable him to ignore the 25th amendment (i.e. the presidential term limit) to run again in 2024 and 2028. From creating the short-lived Presidential Advisory Commission on Election Integrity to track down allegations of fraudulent voting in 2016 to saying that the Congressional hearings on the Mueller report to the Attorney General were treasonous high crimes against him and the nation underscores the growing authoritarian tendencies in the Trump White House. At the same time, Trump has used government agencies to slow the enforcement of legally enacted and longstanding regulatory policies. This selective "slo-mo governance" style increasingly atrophies and obstructs the government's everyday roles in everything from environmental protection to civil rights enforcement.

Since we made the call, Trump became the third president of the United States of America to be impeached and only the fourth to face impeachment hearings. In the spirit of "not normal," 
Republican senators took the astounding position in their hearings on the House's two counts of impeachable offenses that yes, what Trump did was wrong - he abused the Office of the Presidency to extort a foreign government (Ukraine) to release results of an investigation of his main political opponent. But Republican Senators, 1) claimed they could not get into overturning the will of the people; 2) argued Trump had the power as president to do so; therefore nothing here in this instance was illegal; and/or 3) the case of his fitness as president would be judged by the electorate on these and many other issues later in November 2020 election. Republican senators overwhelmingly voted to acquit Donald J. Trump of his impeachment charges with lone Republican Sen. Mitt Romney voting in favor of one article of impeachment.

In this special issue of Fast Capitalism, the contributors look at many dimensions of the Trump Administration to judge its abnormality against the larger canvas of America's democratic governance traditions. At times, Trump's actions appear outside the typical discursive frames of American politics, while at other times, his actions appear to be business-as-usual. The essays, then, emphasize both the continuities and discontinuities in the presidency of Donald J. Trump.

For Nancy Love, Donald Trump's seemingly erratic and egotistic governance style stresses "the art of the deal." She emphasizes, however, the ways in which such deal-making as decisionmaking has much in common with the brusque traditions of authoritarian rule in fascist regimes. In Steven Panageotou's analysis, President Trump's governing style becomes a continuous marketing campaign to develop and expand the appeal of his own personal and family corporate brand. According to Richard Holtzman, Trump's incredibly improvisational communicative style of recurrent rhetorical rips remake national governance into deinstitutionalized personal interventions almost always "on the run" and "off the cuff." Peter Ore and Andrew Davis contend in a similar vein that while Trump has increased the role of the executive branch of government, he has simultaneously disempowered the larger federal bureaucracy. While Donald Trump's never-ending political theatrics are often carnivalesque, Charles Thorpe's contribution carefully analyzes the various ways in which his carnival reflects the ragged realities of American national politics as it unfolds inside the beltway around D.C. Timothy W. Luke turns these oftendecried "constitutional crises" that have repeatedly cropped up during Trump's presidency as a continuation of a deeper "Crisis Constitution" that has unfolded since the revelation of differently depraved abuses of authority during the Nixon presidency and the "New Republican Majority" the GOP forged during the deeply divisive 1968 and 1972 national campaigns for the White House. Far from being abnormal, Luke contends that Trump is a more unstable and dangerous continuation of the civic formulae behind the post-Nixon national political order. In Zachary Wheeler's analysis, Trump now governs both over and through the cruel collapse of neoliberalism. However, since the left and center cannot admit to the flawed failures of American neoliberalism, Trump exploits its flaws to create a new type of far-right neoliberal fascism. Sean Doody explores the growing importance of the "Intellectual Dark Web," a vast dumpster fire of ideological reactions where alt-right figures attempt to create intellectual reactionary forces to counter mainstream science and reason. Doody's account traces Trump's connection to this "intellectual" movement, although the President would admit his actions are being animated by such an intellectual turn. Cary Fraser argues that Trump's attempts to place more power in the presidency disrupts the Founders' purposeful establishment of a careful, if always contentious, balance of power between the three branches of government. The result is a dysfunctional government that might well succumb to the civic collapse the Founders' sought to avoid. Simon Orpana and Evan Mauro read Trump's new concoctions of "vile sovereignty" through the popular 
movie “The Joker." They mobilize Foucault's concept "vile sovereignty" to examine how Trump's toxic masculinity is an attempt to create anxieties among the populace. David G. Embrick, J. Scott Carter, Cameron Lippard, and Bhoomi K. Thakore present the major characteristics of Trump's "not normal" presidency as a direct result of "whitelash" - "individual, institutional, and/or structural countermeasures against the dismantling of white supremacy or actions, real or imagined, that seek to remedy existing racial inequities." Viewed through this analytical lens, Trump's presidency is not so much an abnormality as the normal functioning of white supremacy and institutional racism, which, of course, continuously denies such social pathologies are "not normal" even as the "whitelash" underpinning his administration make them more and more common features of American government in the twenty-first century.

\section{References}

Blake, Aaron. 2020. "Incoming White House Press Kellner, Douglas. 2019. "Donald Trump, Media Secretary Kayleigh McEnany Accused Democrats of Spectacle, and Authoritarian Populism.” Fast Rooting for the Coronavirus." Washington Post, April 7. Capitalism 14(1).

Burns, Katelyn. 2020. “Trump Called Governors 'Weak' Obeidallah, Dean. 2020. “Team Trump Can't Erase the and Said They Need to 'Dominate' George Floyd Boss' Coronavirus 'Hoax." The Daily Beast, April 8. Protesters." Vox, June 1.

Costa, Robert, Seung Min Kim, and Josh Dawsey. n.d. “'Trump Calls Governors 'Weak,' Urges Them to Use Force against Unruly Protests.” Washington Post. 